\title{
Review
}

\section{Feline Leishmaniosis: An Emerging Public Health Problem}

\author{
Ana Elena Ahuir-Baraja, María Pilar Ruiz, María Magdalena Garijo *(i) and Lola Llobat *(i) \\ Department of Animal Production and Health, Veterinary Public Health and Food Science and \\ Technology (PASAPTA), Facultad de Veterinaria, Universidad Cardenal Herrera CEU-CEU Universities, \\ 46115 Valencia, Spain; ana.ahuir@uchceu.es (A.E.A.-B.); ruirodmar1@alumnos.uchceu.es (M.P.R.) \\ * Correspondence: marilena@uchceu.es (M.M.G.); maria.llobatbordes@uchceu.es (L.L.)
}

check for

updates

Citation: Ahuir-Baraja, A.E.; Ruiz, M.P.; Garijo, M.M.; Llobat, L. Feline Leishmaniosis: An Emerging Public Health Problem. Vet. Sci. 2021, 8, 173. https://doi.org/10.3390/vetsci8090173

Academic Editor: Stefania Hanau

Received: 6 August 2021

Accepted: 28 August 2021

Published: 30 August 2021

Publisher's Note: MDPI stays neutral with regard to jurisdictional claims in published maps and institutional affiliations.

Copyright: (C) 2021 by the authors Licensee MDPI, Basel, Switzerland. This article is an open access article distributed under the terms and conditions of the Creative Commons Attribution (CC BY) license (https:/ / creativecommons.org/licenses/by/ $4.0 /)$.

\begin{abstract}
Leishmaniosis is the third most important vector-borne disease in humans, preceded by malaria and lymphatic filariasis, and it is considered endemic in tropical and subtropical areas, where higher temperatures favor development of its vector, sandflies. This zoonotic disease is caused by infection of protozoa Leishmania spp. and the most serious mucocutaneous and visceral form is produced by Leishmania infantum, which predominates in the Mediterranean region. The usual hosts for this parasite are dogs and humans, but an increment in cases of L. infantum infection has been observed in cats in the last years. This increase could be due to the use of sandflies repellents in dogs, obligating the parasite to looking for other hosts. The role of cats in the epidemiology of this disease is unknown, although increase of prevalence of feline leishmaniosis has been observed in endemic areas in the last years. Diagnostic techniques and treatments in cats are not standardized, which makes it difficult to establish prevalence and epidemiology of feline leishmaniosis. Furthermore, the clinical signs and immune response against Leishmania in cats are different to those in dogs, with an observed increment of drug resistance. It is necessary to increase our knowledge about $L$. infantum infection in cats, including clinical signs, transmission, treatments, and the role of cats in the increasing of zoonoses. Finally, new alternative treatments are required for controlling the spread of this disease in all species of mammals.
\end{abstract}

Keywords: cats; feline leishmaniosis; Leishmania infantum; zoonoses

\section{Introduction}

Leishmaniosis is a disease caused by the infection of protozoan parasite Leishmania spp. and transmitted by sandflies of the family Psychodidae (genus Phlebotomus in the Mediterranean region) [1-4]. The World Health Organization (WHO) estimates between 700,000 and 1,000,000 new cases in humans annually. This parasitosis is the third most important vector-born disease in humans, only preceded by malaria and lymphatic filariases, and it is considered endemic in tropical and subtropical areas, where the higher temperatures favor the development of sandflies [5]. Humans, together with domestic dogs (Canis lupus familiaris), are the main hosts, in which the diseases, caused by Leishmania infantum, represent an important problem for public health [6]. Infection in other animals, such as cats (Felis catus), wild canids, and horses, has been reported [7-9]. Although dogs used to be considered uniquely and mainly responsible for the spread of the disease to human, the increase in the number of cases diagnosed in domestic cats $[10,11]$, and $L$. infantum parasites detected in cats sharing the same genetic characteristics with L. infantum strains isolated from humans and dogs [12-14], indicate that this species may play an important role currently in the epidemiology of infection in humans and dogs.

The first case of feline leishmaniosis (FL) was detected by Sergent et al. (1912) in Argelia [15]. FL cases have been described later in Europe, Latin America, and Asia, and their prevalence has increased considerably in recent years, with results of prevalence from $1.3 \%$ in Portugal or Qatar, to $22.5 \%$ and $25 \%$ in Brazil and Iran, respectively [10,16-21]. Although the highest prevalence of feline leishmaniosis has been found in countries where 
the disease is endemic, there are cases reported in other areas as well, such as the United States [22]. This FL rise could be connected with a host change due to the use of sandfly repellents in dogs, making them look for other hosts in which feed on [23,24]. In fact, the number of human leishmaniosis is also increasing, probably because the human companion animal bond is becoming higher with dogs and cats, rising the probability of infection [25]. Furthermore, some studies indicate that the use of secondary hosts by the parasite could be related to an increase in the virulence of L. infantum in humans. Concretely, human leishmaniosis outbreak in Spain with high virulence seems to be related to wild hares and wild rabbit's infection. Both species were found to be asymptomatic reservoirs for the parasite in an area with a low dog population density [26,27]. Early detection of infection in dogs and cats, together with its surveillance and treatments, are strategies to control and avoid human infection, following the "One Health" concept. In addition, and considering cats as emergent hosts with a possible role in the spread of the disease, a new evaluation for the epidemiology and control in this species is necessary [6,28]. However, detection in cats is often confused with other infections, as the clinical signs of leishmaniasis in cats are nonspecific. Furthermore, in some cases, disease appears without clinical signs, making its detection and control more difficult. Moreover, immunosuppression provoked by viruses such as those causing leukemia or feline immunodeficiency can increase parasite multiplication [7]. Due to the scarce information about the role of cats in the distribution of the disease or as reservoir, it is necessary to carry out studies focused on FL, as it could also constitute a point of infection for humans.

In this review, the current knowledge about leishmaniosis in cats is summarized and revised. Comments about the detection and control techniques are included, as well as possible treatments against feline Leishmania spp. infections.

\section{Epidemiology of Feline Leishmaniosis}

Leishmaniosis is a zoonotic disease produced by parasites of genus Leishmania, mainly by the species L. infantum or L. chagasi in America [25]. Its principal host is domestic dogs (Canis lupus familiaris), but parasites have been isolated in rodents, lagomorphs, and wild canids, although the role of these species in the spread of the disease is not clear $[8,26,29-37]$.

In cats, different species of Leishmania spp. have been identified, such as L. infantum, L. mexicana, L. venezuelensis, L. braziliensis, and L. amazonensis [25,38]. Recently, the first case of FL caused by L. amazonensis has been reported [39]. The transmission between host species is carried out through the bite of two genera of mosquitoes, Phlebotomus spp. and Lutzomyia spp. (Psychodidae) $[19,25]$, but L. infantum has been isolated in fleas, ticks, and other arthropods, so they could also play an important role in the transmission even in cats $[40,41]$. Despite the fact that vertical and horizontal transmission are not well studied in felines [42], Vioti et al. (2021) have demonstrated by in vivo studies that infected cats are capable of transmitting L. infantum to sandflies [43]. Positive tests of L. infantum in cats have been reported in different countries in Europe and with different methods in the last twenty years (Table 1), showing the increasing relevance of cats in the transmission of the disease. Moreover, the existence of asymptomatic infection by L. infantum in apparently healthy stray cats has been demonstrated in Spain [44], which increases the importance of carrying out studies in cats as transmitters of the infection, mainly in endemic areas. 
Table 1. Countries where high positive percentage of cases of L. infantum infection in cats have been reported and detection method (IFAT: immunofluorescence antibody test; DAT: direct agglutination test; PCR: polymerase chain reaction; ELISA: enzyme-linked immunosorbent assay). The material analyzed was serum samples for IFAT and ELISA tests, and whole blood for PCR test. * In this study, the authors analyze the antibodies to Leishmania spp.

\begin{tabular}{|c|c|c|c|}
\hline Country & Method of Detection & Positive $\%$ Founded & References \\
\hline Albania & IFAT and PCR & 0.7 & [45] \\
\hline Cyprus & ELISA and PCR & 5.8 & [46] \\
\hline $\begin{array}{c}\text { Greece (Macedonia and } \\
\text { Thessaly) }\end{array}$ & IFAT, ELISA and PCR & 46.0 & {$[47,48]$} \\
\hline Italy (Sicily) & ELISA and PCR & 36.0 & [49] \\
\hline Portugal (Lisbon) & IFAT and PCR & 20.4 & [24] \\
\hline Portugal (Madeira Island) & DAT & 0.0 & [50] \\
\hline Spain (South) & IFAT and PCR & 48.3 & [7] \\
\hline Germany & IFAT and PCR & 4.0 & [51] \\
\hline Qatar (Doha) & PCR & 1.3 & [21] \\
\hline Brazil (Amazon region) & IFAT & 30.5 & [52] \\
\hline Angola (Luanda) * & DAT & 3.9 & [53] \\
\hline Iran (Kerman) & PCR & 13.9 & [54] \\
\hline Israel & ELISA & 75.0 & [55] \\
\hline
\end{tabular}

Different prevalence of infection according to sex in non-neutering animals has never been observed, but factors such as age; neutering status; or co-infection with viruses as feline immunodeficiency virus (FIV) or feline leukemia virus (FeLV), mycoplasmas or other parasites, including Toxoplasma gondii (Protozoa), seem to be considered a determinant factor [53,56-58]. Table 2 summarizes the different organisms, including bacteria, viruses, and other protozoan detected in co-infection with L. infantum in cats.

Table 2. Organisms (including bacteria, viruses, and protists) founded in co-infection with L. infantum in cats.

\begin{tabular}{cc}
\hline Organisms & Reference \\
\hline $\begin{array}{c}\text { Hepatozoon felis and Candidatus mycoplasma } \\
\text { haemominutum }\end{array}$ & {$[59]$} \\
\hline Toxoplasma gondii & {$[53,60]$} \\
\hline $\begin{array}{c}\text { Feline immunodeficiency virus (FIV) and feline } \\
\text { leukemia virus (FeLV) }\end{array}$ & {$[56,61]$} \\
\hline Mycoplasma spp., FIV and FeLV & {$[57]$} \\
\hline Toxoplasma gondii and FIV & {$[58]$} \\
\hline Rickettsia felis & {$[62]$} \\
\hline Ehrlichia spp. and Bartonella spp. & {$[63]$} \\
\hline Babesia spp. (only in wild cats) & {$[64]$} \\
\hline Hepatozoon spp. (only in wild cats) & {$[64]$} \\
\hline
\end{tabular}

\section{Immune Response and Clinical Signs in Cats}

First system of defense in all mammals is physic-chemical barriers, which are not efficient against Leishmania spp. infections, allowing sandfly mouthparts to pass through the skin injecting promastigotes. After that, the immune system and, more specifically, 
innate immunity, such as macrophages, neutrophils, and natural killer (NK) cells, are the first mechanisms against infection [65-67]. The parasite has the ability to survive phagocytization by macrophages, where promastigotes develop into amastigotes [68]. Specific immunity consists in Th1 and Th2 lymphocytes as well as antibodies production, which are unable to eliminate the parasites and can even favor its growth and proliferation. Antibodies are deposited in kidneys, causing glomerulonephritis, and subsequent kidney failure [38]. Contrary to what happens in dogs, a high number of antibodies in cat blood is not related with positive PCR. This explains the high number of cats without clinical signs, which can show skin lesions before they produce antibodies, and low prevalence of kidney failure. Additionally, in most cases of FL, spontaneous remission of clinical signs is frequent, which may be due to the Th1 immune response that gives rise to seroconversion followed by clinical resolution [69]. While in dogs leishmaniosis is a chronic and progressive disease which affects all tissues and organs, in cats this pathology affects commonly spleen, liver, lymph nodes, bone marrow, kidney, and eyes, dermatological and mucocutaneous being the most frequent clinical forms (Figure 1) and more frequent than dogs [23,70-73]. In fact, a recent systematic review summarizes the skin lesions in feline leishmaniosis, indicating that the most reported clinical signs were nodules, followed by ulcers, which were less frequently reported [74]. The most frequent clinical and clinicopathological abnormalities reported in feline leishmaniosis were skin and/or muco-cutaneous nodules and ulcers, and lymphadenomegaly [74].

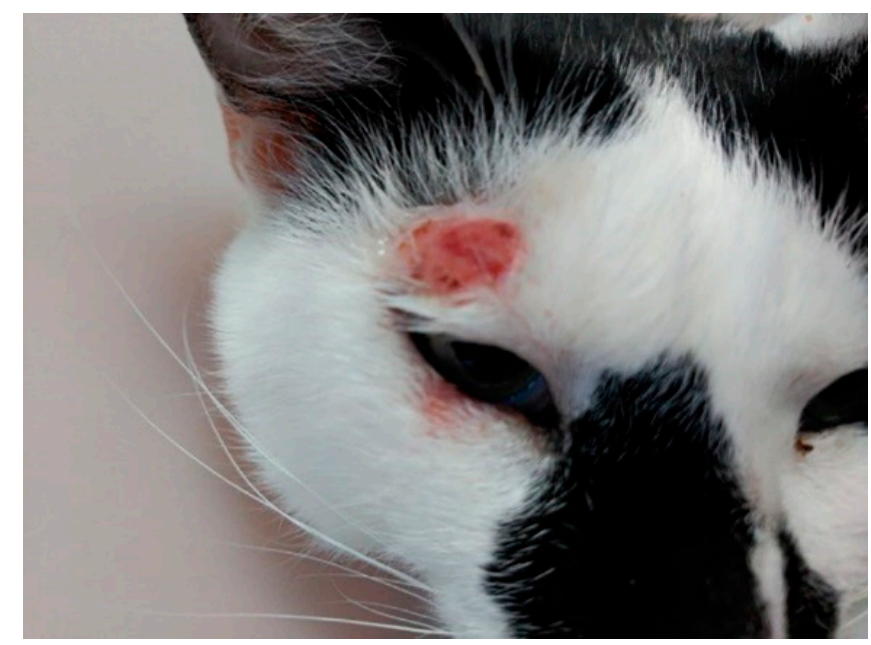

Figure 1. Ulcerative lesion in the temporal area of head related to L. infantum feline infection.

Actually, clinical signs in cats could be due to co-infection with immunosuppressive disease such as cancer or viruses infection [38,42]. Thus, feline immunodeficiency (FIV) or feline leukemia (FeLV) viruses may favor the development of FL. Correlation with leishmaniosis has not been demonstrated yet in cats, although a correlation with similar pathologies as HIV in humans and dogs is well documented [70,75,76]. Different prevalence of L. infantum infection in dogs and cats agrees with the fact that cats seem to present low reaction to parasites [61]. Co-infections with Hepatozoon felis (protists) and Candidatus mycoplasma haemominutum (bacteria) have been also reported [59] (Table 1). Other diseases that can be related with the improvement in the detection of clinical signs of FL are carcinomas, for which correlation in humans and dogs has been demonstrated [77]. Maia et al. (2015) presented for the first time a clinical report of FL associated with an invasive squamous cell carcinoma in a cat [24].

On another hand, different prevalence of L. infantum infection in dogs and cats could be explained because cats seem to present low reaction to parasites. Recently, higher blood parasite burdens have been observed in dogs than in cats with the same exposition to sandflies. Nevertheless, seroactivity in cats was higher than in dogs, so it seems cats are less effective in transmitting the disease [55]. 


\section{Diagnosis of FL}

Laboratory analyses to direct or indirect diagnosis of leishmaniosis are made by serological, parasitological, and molecular techniques [24,78]. Serological tests may be not sensitive enough, so it is necessary to combine them with other techniques such as parasitological or molecular methods in cats [24]. Iatta et al. (2020) have recently developed a new immunofluorescence antibody test with good results for the detection of L. infantum infection in cats [79]. In clinical practice, satisfactory results have been obtained for FL detection by polymerase chain reaction (PCR), as it occurs in the detection of other diseases like feline herpes virus [28]. Molecular techniques, as PCR, have high sensibility to confirm presence of L. infantum, but detection of DNA does not implicate infection in cats [38]. Direct immunofluorescent assay (DIA) has been applied for diagnosing visceral leishmaniosis in cats, using the same cut-off as for dogs, but the results obtained are probably underestimating the infections in cats, as the cats present lower antibody values than dogs [80]. Enzyme-linked immunosorbent assay (ELISA) is also used for diagnosis of FL, showing discrepant results compared with other techniques, which suggest that it should be combined with other parasitological and/or molecular techniques [81]. The immunological diagnostic methods recommended by LeishVet Guideline (2018) were IFAT with cut-off of 1:80, ELISA, DAT, with cut-off of 1/800, Western blot where a $18 \mathrm{kDa}$ band should be detected [74]. As for dogs, interferon gamma (IFN- $\gamma$ ) analysis in cat's blood could provide a better estimation of cat exposure to the disease when it is associated to serological and molecular tests [48,82]. Recently, Savioli et al. (2021) and Urbani et al. (2020) showed that elevated levels of amyloid A, gamma globulins, and alpha 2 globulins could be a good indicator of disease in cats $[83,84]$, although more studies will be necessary to find definitive markers of disease.

Most epidemiological studies have been carried out on visceral leishmaniosis diagnosis and only some of them have analyzed cutaneous or mucocutaneous leishmaniosis. In the latter form, ELISA and indirect fluorescent antibody (IFA) methods are the most sensible for the diagnosis, along with Western blotting (WB), as they present between $97 \%$ to 100\% of specificity [78]. Persichetti et al. (2017) compared ELISA, IFA, and WB techniques and concluded that ELISA is more adequate for the diagnosis of clinical leishmaniosis, but IFA and WB are more sensible methods and, therefore, they should be used for the diagnosis of the subclinical forms [81].

When cutaneous lesions are present (Figure 1), fine-needle aspiration puncture from the skin nodules can be helpful to determine granulomatous inflammation, typically produced by Leishmania spp., and observed in ocular lesions of cats. Ear and nasal planum lesions are considered as differential diagnoses of squamous cell carcinoma [69-71,85]. Without cutaneous lesions, cats could present granulomatous rhinitis [86]. Histiocytic infiltration of tissue, a typical sign of canine leishmaniosis, is not a specific marker in FL [87]. In visceral leishmaniosis, cytology is useful to detect lymphoid hypoplasia in spleen, with the presence of amastigotes, inflammatory infiltrated liver mainly composed of macrophages in the portal area and between hepatocytes $[69,88]$. In summary, clinical signs of FL are similar to those shown in canine leishmaniosis, but with specific features, such as ulcerative and nodular skin lesions [72,89]. Additionally, a case of FL with inflammatory mammary gland fluid has been described [90]. Since many of the clinical signs showed in infected cats are due to comorbidities (Table 1), it is necessary to try to differentiate clinic-pathological abnormalities due to FL. In fact, these co-infections can be present in around $10 \%$ of infected cats by L. infantum [91]. Chatzis et al. (2020) have recently published a study to determine clinical signs of FL, assessing whether the disease is associated with laboratory abnormalities analysis [47]. Diagnosis of FL is clearly difficult, and all these data could explain the high number of infected asymptomatic cats, increasing its importance as a vector for transmitting the parasite to humans.

The identification of Leishmania spp. is also very important for diagnosis, treatment, and management of the disease. However, it is not always easy, since molecular techniques 
are needed, based on high resolution melting or specific markers analysis, to improve results $[11,92]$.

\section{Possible Treatments and Control of Disease}

Approximately half of the cats infected by Leishmania spp. may recover spontaneously, although the studies about the specific treatment are limited, and the actual efficacy of the treatments is unknow [7]. Administration of allopurinol seems to improve clinical signs, but it is not yet known if it may cause relapses as it does in dogs [22,93,94]. The LeishVet Guidelines (2018) recommended treatment of allopurinol $10 \mathrm{mg} / \mathrm{kg} 12 \mathrm{~h}$, or $20 \mathrm{mg} / \mathrm{kg}$ $24 \mathrm{~h}$, for at least 6 months [74]. Other treatments combine allopurinol with meglumine antimoniate, but some authors indicate that only the latter presents a good clinical response in cats $[38,42]$. Nonetheless, lower effects of antimonials, as meglumine antimoniate, have been observed due to the increase of Leishmania spp. drug resistance, even though the mechanism of resistance remains unclear [95]. Flavonoids as fisetin have also been tested and it seems that they prevent promastigotes growth in culture [96].

Considering there is currently no definitive treatment, either for dogs or cats, prevention is essential to reduce the prevalence of this zoonosis, especially in endemic areas. The use of repellents is the most common method for preventing leishmaniosis in dogs. Nevertheless, usual repellents as pyrethrins and pyrethroids are toxic to cats [97]. Nowadays, the unique method for prevention in cats is the use of a polymer collar composed by $10 \%$ imidacloprid and $4.5 \%$ flumethrin. It shows a $75 \%$ of efficacy against FL, and it also protects against ticks, fleas, and other arthropods [98]. In regard to vaccines, while there are one or two (depending of country) commercial ones against leishmaniosis in dogs, none have been synthetized for FL $[99,100]$. Factors such as cleaning of environment where cats live and avoiding outdoor access could be helpful in the prevention of L. infantum infection in cats [52].

\section{Conclusions}

The use of sandfly repellents in domestic dogs (Canis lupus familiaris) for avoiding leishmaniosis has caused the parasite to hunt for other mammalian hosts. Given that there is evidence of an increase in the virulence of the parasite when infecting a secondary host, it is of great relevance for the global health of both animals and humans to control and eradicate Leishmania spp. infection in all species of mammals. One of these new target hosts are domestic cats (Felis catus), in which an increase of leishmaniosis by L. infantum infection has been observed in recent years, mainly in areas where the disease is endemic. Epidemiology and prevalence of infection in cats is little known and the results are very different, depending on the technique used for the diagnosis or the geographical area. Regardless of this disparity in the data collected so far on the prevalence of infection in cats, an increase in cases is beginning to be worrying, especially since cats are the second most frequent pet in the world. On the other hand, there is little knowledge about clinical signs of the disease in cats and these cannot be compared to those found in dogs, since the two species present significant differences in their immune response to pathogens, such as the antibody titers in blood. In this way, the usual clinical practice applied in dogs is not useful for infected cats. In addition, around half of infected cats recover spontaneously, so the danger of this species as a reservoir for the parasite increases. The fact that we cannot use the same repellents as in dogs, and the increase of drug resistant parasites, makes it necessary to carry out more studies to expand the knowledge on clinical and preventive aspects to reduce or eradicate this zoonosis in cats.

Author Contributions: Conceptualization, M.M.G. and A.E.A.-B.; methodology, M.M.G.; writingoriginal draft preparation, M.P.R.; writing—review and editing, L.L. and M.M.G.; supervision, L.L. All authors have read and agreed to the published version of the manuscript. 
Funding: This work was funded by the grants for emerging research groups of Generalitat Valenciana (GV/2021/104). The funding agency was not involved in design of study, data collection, analysis of data, or manuscript writing.

Institutional Review Board Statement: Not applicable.

Informed Consent Statement: Not applicable.

Data Availability Statement: Not applicable.

Acknowledgments: We are grateful for the support of the Faculty of Veterinary Medicine at the Universidad Cardenal Herrera CEU.

Conflicts of Interest: The authors declare no conflict of interest.

\section{References}

1. Werneck, G.L. Visceral Leishmaniasis in Brazil: Rationale and Concerns Related to Reservoir Control. Rev. Saude Publica 2014, 48, 851-856. [CrossRef]

2. Rombolà, P.; Barlozzari, G.; Carvelli, A.; Scarpulla, M.; Iacoponi, F.; Macrì, G. Seroprevalence and Risk Factors Associated with Exposure to Leishmania Infantum in Dogs, in an Endemic Mediterranean Region. PLoS ONE 2021, 16, e0244923. [CrossRef]

3. Trájer, A.J.; Sebestyén, V. The Changing Distribution of Leishmania Infantum Nicolle, 1908 and Its Mediterranean Sandfly Vectors in the Last 140 Kys. Sci. Rep. 2019, 9, 11820. [CrossRef] [PubMed]

4. Muñoz, C.; Martínez-de la Puente, J.; Figuerola, J.; Pérez-Cutillas, P.; Navarro, R.; Ortuño, M.; Bernal, L.J.; Ortiz, J.; Soriguer, R.; Berriatua, E. Molecular Xenomonitoring and Host Identification of Leishmania Sand Fly Vectors in a Mediterranean Periurban Wildlife Park. Transbound. Emerg. Dis. 2019, 66, 2546-2561. [CrossRef]

5. Solano-Gallego, L.; Koutinas, A.; Miró, G.; Cardoso, L.; Pennisi, M.G.; Ferrer, L.; Bourdeau, P.; Oliva, G.; Baneth, G. Directions for the Diagnosis, Clinical Staging, Treatment and Prevention of Canine Leishmaniosis. Vet. Parasitol. 2009, 165, 1-18. [CrossRef] [PubMed]

6. Maia, C.; Campino, L. Cytokine and Phenotypic Cell Profiles of Leishmania Infantum Infection in the Dog. J. Trop. Med. 2012, 2012, 541571. [CrossRef] [PubMed]

7. Martín-Sánchez, J.; Acedo, C.; Muñoz-Pérez, M.; Pesson, B.; Marchal, O.; Morillas-Márquez, F. Infection by Leishmania Infantum in Cats: Epidemiological Study in Spain. Vet. Parasitol. 2007, 145, 267-273. [CrossRef]

8. Sobrino, R.; Ferroglio, E.; Oleaga, A.; Romano, A.; Millan, J.; Revilla, M.; Arnal, M.C.; Trisciuoglio, A.; Gortázar, C. Characterization of Widespread Canine Leishmaniasis among Wild Carnivores from Spain. Vet. Parasitol. 2008, 155, 198-203. [CrossRef]

9. Fernández-Bellon, H.; Solano-Gallego, L.; Bardagí, M.; Alberola, J.; Ramis, A.; Ferrer, L. Immune Response to Leishmania Infantum in Healthy Horses in Spain. Vet. Parasitol. 2006, 135, 181-185. [CrossRef]

10. Pennisi, M.G.; Persichetti, M.F. Feline Leishmaniosis: Is the Cat a Small Dog? Vet. Parasitol. 2018, 251, 131-137. [CrossRef]

11. Spada, E.; Canzi, I.; Baggiani, L.; Perego, R.; Vitale, F.; Migliazzo, A.; Proverbio, D. Prevalence of Leishmania Infantum and Co-Infections in Stray Cats in Northern Italy. Comp. Immunol. Microbiol. Infect. Dis. 2016, 45, 53-58. [CrossRef] [PubMed]

12. Pereira, A.; Parreira, R.; Cristóvão, J.M.; Castelli, G.; Bruno, F.; Vitale, F.; Campino, L.; Maia, C. Phylogenetic Insights on Leishmania Detected in Cats as Revealed by Nucleotide Sequence Analysis of Multiple Genetic Markers. Infect. Genet. Evol. 2020, 77, 104069. [CrossRef]

13. Millán, J.; Zanet, S.; Gomis, M.; Trisciuoglio, A.; Negre, N.; Ferroglio, E. An Investigation into Alternative Reservoirs of Canine Leishmaniasis on the Endemic Island of Mallorca (Spain). Transbound. Emerg. Dis. 2011, 58, 352-357. [CrossRef]

14. Cardoso, L.; Schallig, H.; Persichetti, M.F.; Pennisi, M.G. New Epidemiological Aspects of Animal Leishmaniosis in Europe: The Role of Vertebrate Hosts Other Than Dogs. Pathogens 2021, 10, 307. [CrossRef]

15. Sergent, E.; Sergent, E.T.; Lombard, J.; Quilichini, M. La Leishmaniose à Alger. Infection Simultanée d'un Enfant, d'un Chien et d'un Chat Dans La Même Habitation. Bull. Soc. Pathol. Exot. 1912, 5, 93-98.

16. Akhtardanesh, B.; Sharifi, I.; Mohammadi, A.; Mostafavi, M.; Hakimmipour, M.; Pourafshar, N.G. Feline Visceral Leishmaniasis in Kerman, Southeast of Iran: Serological and Molecular Study. J. Vector Borne Dis. 2017, 54, 96-102.

17. Benassi, J.C.; Benvenga, G.U.; Ferreira, H.L.; Pereira, V.F.; Keid, L.B.; Soares, R.; de Sousa Oliveira, T.M.F. Detection of Leishmania Infantum DNA in Conjunctival Swabs of Cats by Quantitative Real-Time PCR. Exp. Parasitol. 2017, 177, 93-97. [CrossRef] [PubMed]

18. Berenguer, L.K.A.R.; de Andrade Gomes, C.F.C.; de Oliveira Nascimento, J.; Bernardi, J.C.M.; Lima, V.F.S.; de Oliveira, J.B.; Ramos, C.A.D.N.; Ramos, R.A.N.; Alves, L.C. Leishmania Infantum Infection in a Domestic Cat: A Real Treat or an Occasional Finding? Acta Parasitol. 2020. [CrossRef]

19. Pennisi, M.G. Leishmaniosis of Companion Animals in Europe: An Update. Vet. Parasitol. 2015, 208, 35-47. [CrossRef]

20. Foroughi-Parvar, F.; Sarkari, B.; Asgari, Q.; Hatam, G. FML-ELISA a Novel Diagnostic Method for Detection of Feline Leishmaniasis in Two Endemic Areas of Iran. J. Parasit. Dis. 2021, 45, 279-284. [CrossRef]

21. Lima, C.; Colella, V.; Latrofa, M.S.; Cardoso, L.; Otranto, D.; Alho, A.M. Molecular Detection of Leishmania spp. in Dogs and a Cat from Doha, Qatar. Parasit. Vectors 2019, 12, 125. [CrossRef] 
22. Hopke, K.; Meyers, A.; Auckland, L.; Hamer, S.; Florin, D.; Diesel, A.; Patterson, A. Leishmania Mexicana in a Central Texas Cat: Clinical Presentation, Molecular Identification, Sandfly Vector Collection and Novel Management. JFMS Open Rep. 2021, 7, 2055116921999595. [CrossRef]

23. Basso, M.A.; Marques, C.; Santos, M.; Duarte, A.; Pissarra, H.; Carreira, L.M.; Gomes, L.; Valério-Bolas, A.; Tavares, L.; SantosGomes, G.; et al. Successful Treatment of Feline Leishmaniosis Using a Combination of Allopurinol and N-Methyl-Glucamine Antimoniate. JFMS Open Rep. 2016, 2, 2055116916630002. [CrossRef] [PubMed]

24. Maia, C.; Gomes, J.; Cristóvão, J.; Nunes, M.; Martins, A.; Rebêlo, E.; Campino, L. Feline Leishmania Infection in a Canine Leishmaniasis Endemic Region, Portugal. Vet. Parasitol. 2010, 174, 336-340. [CrossRef]

25. Gramiccia, M. Recent Advances in Leishmaniosis in Pet Animals: Epidemiology, Diagnostics and Anti-Vectorial Prophylaxis. Vet. Parasitol. 2011, 181, 23-30. [CrossRef]

26. Jiménez, M.; González, E.; Martín-Martín, I.; Hernández, S.; Molina, R. Could Wild Rabbits (Oryctolagus Cuniculus) Be Reservoirs for Leishmania Infantum in the Focus of Madrid, Spain? Vet. Parasitol. 2014, 202, 296-300. [CrossRef] [PubMed]

27. Mas, A.; Martínez-Rodrigo, A.; Orden, J.A.; Molina, R.; Jiménez, M.; Jiménez, M.Á.; Carrión, J.; Domínguez-Bernal, G. Properties of Virulence Emergence of Leishmania Infantum Isolates from Phlebotomus Perniciosus Collected during the Human Leishmaniosis Outbreak in Madrid, Spain. Hepatic Histopathology and Immunological Parameters as Virulence Markers in the Mouse Model. Transbound. Emerg. Dis. 2020. [CrossRef]

28. Oliveira, G.C.; Paiz, L.M.; Menozzi, B.D.; Lima, M.D.S.; Moraes, C.C.G.D.; Langoni, H. Antibodies to Leishmania spp. in Domestic Felines. Rev. Bras. Parasitol. Vet. 2015, 24, 464-470. [CrossRef]

29. Biglino, A.; Bolla, C.; Concialdi, E.; Trisciuoglio, A.; Romano, A.; Ferroglio, E. Asymptomatic Leishmania Infantum Infection in an Area of Northwestern Italy (Piedmont Region) Where Such Infections Are Traditionally Nonendemic. J. Clin. Microbiol. 2010, 48, 131-136. [CrossRef]

30. Dujardin, J.-C.; Campino, L.; Cañavate, C.; Dedet, J.-P.; Gradoni, L.; Soteriadou, K.; Mazeris, A.; Ozbel, Y.; Boelaert, M. Spread of Vector-Borne Diseases and Neglect of Leishmaniasis, Europe. Emerg. Infect. Dis. 2008, 14, 1013-1018. [CrossRef] [PubMed]

31. Helhazar, M.; Leitão, J.; Duarte, A.; Tavares, L.; da Fonseca, I.P. Natural Infection of Synathropic Rodent Species Mus Musculus and Rattus Norvegicus by Leishmania Infantum in Sesimbra and Sintra-Portugal. Parasit. Vectors 2013, 6, 1-6. [CrossRef]

32. Maroli, M.; Feliciangeli, M.D.; Bichaud, L.; Charrel, R.N.; Gradoni, L. Phlebotomine Sandflies and the Spreading of Leishmaniases and Other Diseases of Public Health Concern. Med. Vet. Entomol. 2013, 27, 123-147. [CrossRef]

33. Millán, J.; Ferroglio, E.; Solano-Gallego, L. Role of Wildlife in the Epidemiology of Leishmania Infantum Infection in Europe. Parasitol. Res. 2014, 113, 2005-2014. [CrossRef]

34. Molina, R.; Jiménez, M.I.; Cruz, I.; Iriso, A.; Martín-Martín, I.; Sevillano, O.; Melero, S.; Bernal, J. The Hare (Lepus Granatensis) as Potential Sylvatic Reservoir of Leishmania Infantum in Spain. Vet. Parasitol. 2012, 190, 268-271. [CrossRef]

35. Moreno, I.; Álvarez, J.; García, N.; de la Fuente, S.; Martínez, I.; Marino, E.; Toraño, A.; Goyache, J.; Vilas, F.; Domínguez, L.; et al. Detection of Anti-Leishmania Infantum Antibodies in Sylvatic Lagomorphs from an Epidemic Area of Madrid Using the Indirect Immunofluorescence Antibody Test. Vet. Parasitol. 2014, 199, 264-267. [CrossRef] [PubMed]

36. Poeppl, W.; Herkner, H.; Tobudic, S.; Faas, A.; Auer, H.; Mooseder, G.; Burgmann, H.; Walochnik, J. Seroprevalence and Asymptomatic Carriage of Leishmania spp. in Austria, a Non-Endemic European Country. Clin. Microbiol. Infect. 2013, 19, 572-577. [CrossRef]

37. Scarlata, F.; Vitale, F.; Saporito, L.; Reale, S.; Vecchi, V.L.; Giordano, S.; Infurnari, L.; Occhipinti, F.; Titone, L. Asymptomatic Leishmania Infantum/Chagasi Infection in Blood Donors of Western Sicily. Trans. R. Soc. Trop. Med. Hyg. 2008, 102, 394-396. [CrossRef] [PubMed]

38. Soares, C.S.A.; Duarte, S.C.; Sousa, S.R. What Do We Know about Feline Leishmaniosis? J. Feline Med. Surg. 2016, 18, 435-442. [CrossRef] [PubMed]

39. Carneiro, L.A.; Dos Santos, T.V.; do Rêgo Lima, L.V.; Ramos, P.K.S.; Campos, M.B.; Silveira, F.T. First Report on Feline Leishmaniasis Caused by Leishmania (Leishmania) Amazonensis in Amazonian Brazil. Vet. Parasitol. Reg. Stud. Rep. 2020, $19,100360$. [CrossRef]

40. Colombo, F.A.; Odorizzi, R.M.F.N.; Laurenti, M.D.; Galati, E.A.B.; Canavez, F.; Pereira-Chioccola, V.L. Detection of Leishmania (Leishmania) Infantum RNA in Fleas and Ticks Collected from Naturally Infected Dogs. Parasitol. Res. 2011, 109, 267-274. [CrossRef]

41. Salvatore, D.; Aureli, S.; Baldelli, R.; Di Francesco, A.; Tampieri, M.P.; Galuppi, R. Molecular Evidence of Leishmania Infantum in Ixodes Ricinus Ticks from Dogs and Cats, in Italy. Vet. Ital. 2014, 50, 307-312. [CrossRef]

42. Pennisi, M.G.; Hartmann, K.; Lloret, A.; Addie, D.; Belák, S.; Boucraut-Baralon, C.; Egberink, H.; Frymus, T.; Gruffydd-Jones, T.; Hosie, M.J.; et al. Leishmaniosis in Cats: ABCD Guidelines on Prevention and Management. J. Feline Med. Surg. 2013, 15, 638-642. [CrossRef] [PubMed]

43. Vioti, G.; da Silva, M.D.; Galvis-Ovallos, F.; Alves, M.L.; da Silva, D.T.; Leonel, J.A.F.; Pereira, N.W.B.; Benassi, J.C.; Spada, J.C.P.; Maia, C.; et al. Xenodiagnosis in Four Domestic Cats Naturally Infected by Leishmania Infantum. Transbound. Emerg. Dis. 2021. [CrossRef] [PubMed]

44. Alcover, M.M.; Basurco, A.; Fernandez, A.; Riera, C.; Fisa, R.; Gonzalez, A.; Verde, M.; Garrido, A.M.; Ruíz, H.; Yzuel, A.; et al. A Cross-Sectional Study of Leishmania Infantum Infection in Stray Cats in the City of Zaragoza (Spain) Using Serology and PCR. Parasit. Vectors 2021, 14, 178. [CrossRef] 
45. Silaghi, C.; Knaus, M.; Rapti, D.; Kusi, I.; Shukullari, E.; Hamel, D.; Pfister, K.; Rehbein, S. Survey of Toxoplasma Gondii and Neospora Caninum, Haemotropic Mycoplasmas and Other Arthropod-Borne Pathogens in Cats from Albania. Parasit. Vectors 2014, 7, 62. [CrossRef]

46. Attipa, C.; Papasouliotis, K.; Solano-Gallego, L.; Baneth, G.; Nachum-Biala, Y.; Sarvani, E.; Knowles, T.G.; Mengi, S.; Morris, D.; Helps, C.; et al. Prevalence Study and Risk Factor Analysis of Selected Bacterial, Protozoal and Viral, Including Vector-Borne, Pathogens in Cats from Cyprus. Parasit. Vectors 2017, 10, 130. [CrossRef] [PubMed]

47. Chatzis, M.K.; Xenoulis, P.G.; Leontides, L.; Kasabalis, D.; Mylonakis, M.E.; Andreadou, M.; Ikonomopoulos, J.; Saridomichelakis, M.N. Evaluation of Clinicopathological Abnormalities in Sick Cats Naturally Infected by Leishmania Infantum. Heliyon 2020, 6 , e05177. [CrossRef]

48. Chatzis, M.K.; Andreadou, M.; Leontides, L.; Kasabalis, D.; Mylonakis, M.; Koutinas, A.F.; Rallis, T.; Ikonomopoulos, J.; Saridomichelakis, M.N. Cytological and Molecular Detection of Leishmania Infantum in Different Tissues of Clinically Normal and Sick Cats. Vet. Parasitol. 2014, 202, 217-225. [CrossRef]

49. Priolo, V.; Martínez-Orellana, P.; Pennisi, M.G.; Masucci, M.; Prandi, D.; Ippolito, D.; Bruno, F.; Castelli, G.; Solano-Gallego, L. Leishmania Infantum-Specific IFN- $\gamma$ Production in Stimulated Blood from Cats Living in Areas Where Canine Leishmaniosis Is Endemic. Parasit. Vectors 2019, 12, 133. [CrossRef]

50. Neves, M.; Lopes, A.P.; Martins, C.; Fino, R.; Paixão, C.; Damil, L.; Lima, C.; Alho, A.M.; Schallig, H.D.F.H.; Dubey, J.P.; et al. Survey of Dirofilaria Immitis Antigen and Antibodies to Leishmania Infantum and Toxoplasma Gondii in Cats from Madeira Island, Portugal. Parasit. Vectors 2020, 13, 117. [CrossRef]

51. Schäfer, I.; Kohn, B.; Volkmann, M.; Müller, E. Retrospective Evaluation of Vector-Borne Pathogens in Cats Living in Germany (2012-2020). Parasit. Vectors 2021, 14, 123. [CrossRef]

52. Rocha, A.V.V.O.; Moreno, B.F.S.; Cabral, A.D.; Louzeiro, N.M.; Miranda, L.M.; Dos Santos, V.M.B.; da Costa, A.P.; Nogueira, R.D.M.S.; Marcili, A.; Sperança, M.A.; et al. Diagnosis and Epidemiology of Leishmania Infantum in Domestic Cats in an Endemic Area of the Amazon Region, Brazil. Vet. Parasitol. 2019, 273, 80-85. [CrossRef] [PubMed]

53. Lopes, A.P.; Oliveira, A.C.; Granada, S.; Rodrigues, F.T.; Papadopoulos, E.; Schallig, H.; Dubey, J.P.; Cardoso, L. Antibodies to Toxoplasma Gondii and Leishmania spp. in Domestic Cats from Luanda, Angola. Vet. Parasitol. 2017, 239, 15-18. [CrossRef] [PubMed]

54. Akhtardanesh, B.; Moeini, E.; Sharifi, I.; Saberi, M.; Sadeghi, B.; Ebrahimi, M.; Otranto, D. Leishmania Infection in Cats Positive for Immunodeficiency Virus and Feline Leukemia Virus in an Endemic Region of Iran. Vet. Parasitol. Reg. Stud. Rep. 2020, 20, 100387. [CrossRef] [PubMed]

55. Baneth, G.; Nachum-Biala, Y.; Zuberi, A.; Zipori-Barki, N.; Orshan, L.; Kleinerman, G.; Shmueli-Goldin, A.; Bellaiche, M.; Leszkowicz-Mazuz, M.; Salant, H.; et al. Leishmania Infection in Cats and Dogs Housed Together in an Animal Shelter Reveals a Higher Parasite Load in Infected Dogs despite a Greater Seroprevalence among Cats. Parasit. Vectors 2020, 13, 115. [CrossRef]

56. Iatta, R.; Furlanello, T.; Colella, V.; Tarallo, V.D.; Latrofa, M.S.; Brianti, E.; Trerotoli, P.; Decaro, N.; Lorusso, E.; Schunack, B.; et al. A Nationwide Survey of Leishmania Infantum Infection in Cats and Associated Risk Factors in Italy. PLoS Negl. Trop. Dis. 2019, 13, e0007594. [CrossRef]

57. Marcondes, M.; Hirata, K.Y.; Vides, J.P.; Sobrinho, L.S.V.; Azevedo, J.S.; Vieira, T.S.W.J.; Vieira, R.F.C. Infection by Mycoplasma spp., Feline Immunodeficiency Virus and Feline Leukemia Virus in Cats from an Area Endemic for Visceral Leishmaniasis. Parasit. Vectors 2018, 11, 131. [CrossRef]

58. Miró, G.; Rupérez, C.; Checa, R.; Gálvez, R.; Hernández, L.; García, M.; Canorea, I.; Marino, V.; Montoya, A. Current Status of L. Infantum Infection in Stray Cats in the Madrid Region (Spain): Implications for the Recent Outbreak of Human Leishmaniosis? Parasit. Vectors 2014, 7, 112. [CrossRef]

59. Attipa, C.; Neofytou, K.; Yiapanis, C.; Martínez-Orellana, P.; Baneth, G.; Nachum-Biala, Y.; Brooks-Brownlie, H.; Solano-Gallego, L.; Tasker, S. Follow-up Monitoring in a Cat with Leishmaniosis and Coinfections with Hepatozoon Felis and "Candidatus Mycoplasma Haemominutum". JFMS Open Rep. 2017, 3, 2055116917740454. [CrossRef] [PubMed]

60. Duarte, A.; Castro, I.; Pereira da Fonseca, I.M.; Almeida, V.; Madeira de Carvalho, L.M.; Meireles, J.; Fazendeiro, M.I.; Tavares, L.; Vaz, Y. Survey of Infectious and Parasitic Diseases in Stray Cats at the Lisbon Metropolitan Area, Portugal. J. Feline Med. Surg. 2010, 12, 441-446. [CrossRef]

61. Grevot, A.; Jaussaud Hugues, P.; Marty, P.; Pratlong, F.; Ozon, C.; Haas, P.; Breton, C.; Bourdoiseau, G. Leishmaniosis Due to Leishmania Infantum in a FIV and FelV Positive Cat with a Squamous Cell Carcinoma Diagnosed with Histological, Serological and Isoenzymatic Methods. Parasite 2005, 12, 271-275. [CrossRef]

62. Morelli, S.; Crisi, P.E.; Di Cesare, A.; De Santis, F.; Barlaam, A.; Santoprete, G.; Parrinello, C.; Palermo, S.; Mancini, P.; Traversa, D. Exposure of Client-Owned Cats to Zoonotic Vector-Borne Pathogens: Clinic-Pathological Alterations and Infection Risk Analysis. Comp. Immunol. Microbiol. Infect. Dis. 2019, 66, 101344. [CrossRef]

63. Pedrassani, D.; Biolchi, J.; Gonçalves, L.R.; Mendes, N.S.; Zanatto, D.C.D.S.; Calchi, A.C.; Machado, R.Z.; André, M.R. Molecular Detection of Vector-Borne Agents in Cats in Southern Brazil. Rev. Bras. Parasitol. Vet. 2019, 28, 632-643. [CrossRef]

64. Ortuño, M.; Nachum-Biala, Y.; García-Bocanegra, I.; Resa, M.; Berriatua, E.; Baneth, G. An Epidemiological Study in Wild Carnivores from Spanish Mediterranean Ecosystems Reveals Association between Leishmania Infantum, Babesia spp. and Hepatozoon spp. Infection and New Hosts for Hepatozoon Martis, Hepatozoon Canis and Sarcocystis spp. Transbound. Emerg. Dis. 2021. [CrossRef] 
65. Ferrer i Caubet, L.; Cortadellas, Ó.; Fariñas Guerrero, F.; Moreno, J.; Oliva, G.; Roura López, X.; Sanz Herrera, F.; Tarragó, A.; Vich Cordón, C. La Leishmaniosis Canina, Una Visión Práctica; Ediciones S: Barcelona, Spain, 2016; ISBN 978-84-87736-88-9.

66. Pereira, M.A.; Alexandre-Pires, G.; Câmara, M.; Santos, M.; Martins, C.; Rodrigues, A.; Adriana, J.; Passero, L.F.D.; Pereira da Fonseca, I.; Santos-Gomes, G. Canine Neutrophils Cooperate with Macrophages in the Early Stages of Leishmania Infantum in Vitro Infection. Parasite Immunol. 2019, 41, e12617. [CrossRef]

67. Pereira, M.; Valério-Bolas, A.; Santos-Mateus, D.; Alexandre-Pires, G.; Santos, M.; Rodrigues, A.; Rocha, H.; Santos, A.; Martins, C.; Tomas, A.; et al. Canine Neutrophils Activate Effector Mechanisms in Response to Leishmania Infantum. Vet. Parasitol. 2017, 248, 10-20. [CrossRef]

68. Esch, K.J.; Petersen, C.A. Transmission and Epidemiology of Zoonotic Protozoal Diseases of Companion Animals. Clin. Microbiol. Rev. 2013, 26, 58-85. [CrossRef]

69. Montoya, A.; García, M.; Gálvez, R.; Checa, R.; Marino, V.; Sarquis, J.; Barrera, J.P.; Rupérez, C.; Caballero, L.; Chicharro, C.; et al. Implications of Zoonotic and Vector-Borne Parasites to Free-Roaming Cats in Central Spain. Vet. Parasitol. 2018, 251, 125-130. [CrossRef]

70. Navarro, J.A.; Sánchez, J.; Peñafiel-Verdú, C.; Buendía, A.J.; Altimira, J.; Vilafranca, M. Histopathological Lesions in 15 Cats with Leishmaniosis. J. Comp. Pathol. 2010, 143, 297-302. [CrossRef]

71. Pocholle, E.; Reyes-Gomez, E.; Giacomo, A.; Delaunay, P.; Hasseine, L.; Marty, P. Un Cas de Leishmaniose Féline Disséminée Dans Le Sud de La France. Parasite 2012, 19, 77-80. [CrossRef]

72. Rivas, A.K.; Alcover, M.; Martínez-Orellana, P.; Montserrat-Sangrà, S.; Nachum-Biala, Y.; Bardagí, M.; Fisa, R.; Riera, C.; Baneth, G.; Solano-Gallego, L. Clinical and Diagnostic Aspects of Feline Cutaneous Leishmaniosis in Venezuela. Parasit. Vectors 2018, 11, 141. [CrossRef] [PubMed]

73. Fernandez-Gallego, A.; Feo Bernabe, L.; Dalmau, A.; Esteban-Saltiveri, D.; Font, A.; Leiva, M.; Ortuñez-Navarro, A.; Peña, M.-T.; Tabar, M.-D.; Real-Sampietro, L.; et al. Feline Leishmaniosis: Diagnosis, Treatment and Outcome in 16 Cats. J. Feline Med. Surg. 2020, 22, 993-1007. [CrossRef] [PubMed]

74. Abramo, F.; Albanese, F.; Gattuso, S.; Randone, A.; Fileccia, I.; Dedola, C.; Ibba, F.; Ottaiano, P.; Brianti, E. Skin Lesions in Feline Leishmaniosis: A Systematic Review. Pathogens 2021, 10, 472. [CrossRef]

75. Burza, S.; Croft, S.L.; Boelaert, M. Leishmaniasis. Lancet 2018, 392, 951-970. [CrossRef]

76. Henn, G.A.D.L.; Ramos Júnior, A.N.; Colares, J.K.B.; Mendes, L.P.; Silveira, J.G.C.; Lima, A.A.F.; Aires, B.P.; Façanha, M.C. Is Visceral Leishmaniasis the Same in HIV-Coinfected Adults? Braz. J. Infect. Dis. 2018, 22, 92-98. [CrossRef]

77. Schwing, A.; Pomares, C.; Majoor, A.; Boyer, L.; Marty, P.; Michel, G. Leishmania Infection: Misdiagnosis as Cancer and Tumor-Promoting Potential. Acta Trop. 2019, 197, 104855. [CrossRef] [PubMed]

78. Trevisan, D.A.C.; Lonardoni, M.V.C.; Demarchi, I.G. Diagnostic Methods to Cutaneous Leishmaniasis Detection in Domestic Dogs and Cats. An. Bras. Dermatol. 2015, 90, 868-872. [CrossRef]

79. Iatta, R.; Trerotoli, P.; Lucchese, L.; Natale, A.; Buonavoglia, C.; Nachum-Biala, Y.; Baneth, G.; Otranto, D. Validation of a New Immunofluorescence Antibody Test for the Detection of Leishmania Infantum Infection in Cats. Parasitol. Res. 2020, 119, 1381-1386. [CrossRef]

80. Fatollahzadeh, M.; Khanmohammadi, M.; Bazmani, A.; Mirsamadi, N.; Jafari, R.; Mohebali, M.; Nemati, T.; Fallah, E. Survey of Feline Visceral Leishmaniasis in Azarshahr Area, North West of Iran, 2013. J. Parasit. Dis. 2016, 40, 683-687. [CrossRef]

81. Persichetti, M.F.; Solano-Gallego, L.; Vullo, A.; Masucci, M.; Marty, P.; Delaunay, P.; Vitale, F.; Pennisi, M.G. Diagnostic Performance of ELISA, IFAT and Western Blot for the Detection of Anti-Leishmania Infantum Antibodies in Cats Using a Bayesian Analysis without a Gold Standard. Parasit. Vectors 2017, 10, 119. [CrossRef]

82. Martínez-Orellana, P.; Quirola-Amores, P.; Montserrat-Sangrà, S.; Ordeix, L.; Llull, J.; Álvarez-Fernández, A.; Solano-Gallego, L. The Inflammatory Cytokine Effect of Pam3CSK4 TLR2 Agonist Alone or in Combination with Leishmania Infantum Antigen on Ex-Vivo Whole Blood from Sick and Resistant Dogs. Parasit. Vectors 2017, 10, 123. [CrossRef] [PubMed]

83. Savioli, G.; Archer, J.; Brianti, E.; Benelli, G.; Schnyder, M.; Iatta, R.; Otranto, D.; Cantacessi, C. Serum Amyloid A Levels and Alpha 2 and Gamma Globulins on Serum Protein Electrophoresis in Cats Exposed to and Infected with Leishmania Infantum. Parasit. Vectors 2021, 14, 217. [CrossRef] [PubMed]

84. Urbani, L.; Tirolo, A.; Salvatore, D.; Tumbarello, M.; Segatore, S.; Battilani, M.; Balboni, A.; Dondi, F. Serological, Molecular and Clinicopathological Findings Associated with Leishmania Infantum Infection in Cats in Northern Italy. J. Feline Med. Surg. 2020, 22, 935-943. [CrossRef] [PubMed]

85. Headley, S.A.; Pimentel, L.A.; de Amorim, I.F.G.; Amude, A.M.; Viana, N.E.; Muraro, L.S.; Tafuri, W.L.; Dos Santos, M.D. Immunohistochemical Characterization of Cutaneous Leishmaniasis in Cats from Central-West Brazil. Vet. Parasitol. Reg. Stud. Rep. 2019, 17, 100290. [CrossRef] [PubMed]

86. Leal, R.O.; Pereira, H.; Cartaxeiro, C.; Delgado, E.; Peleteiro, M.D.C.; Pereira da Fonseca, I. Granulomatous Rhinitis Secondary to Feline Leishmaniosis: Report of an Unusual Presentation and Therapeutic Complications. JFMS Open Rep. 2018, 4, 2055116918811374. [CrossRef]

87. Di Mattia, D.; Fondevila, D.; Abramo, F.; Fondati, A. A Retrospective Histopathological, Immunohistochemical and Molecular Study of the Presence of Leishmania spp. in the Skin of Cats with Head and Neck Ulcerative Dermatitis. Vet. Dermatol. 2018, 29, 212-e76. [CrossRef] 
88. Migliazzo, A.; Vitale, F.; Calderone, S.; Puleio, R.; Binanti, D.; Abramo, F. Feline Leishmaniosis: A Case with a High Parasitic Burden. Vet. Dermatol. 2015, 26, 69-70. [CrossRef]

89. Vides, J.P.; Schwardt, T.F.; Sobrinho, L.S.V.; Marinho, M.; Laurenti, M.D.; Biondo, A.W.; Leutenegger, C.; Marcondes, M. Leishmania Chagasi Infection in Cats with Dermatologic Lesions from an Endemic Area of Visceral Leishmaniosis in Brazil. Vet. Parasitol. 2011, 178, 22-28. [CrossRef] [PubMed]

90. Pereira, A.; Valente, J.; Parreira, R.; Cristovão, J.M.; Azinheira, S.; Campino, L.; Maia, C. An Unusual Case of Feline Leishmaniosis with Involvement of the Mammary Glands. Top. Companion. Anim. Med. 2019, 37, 100356. [CrossRef]

91. Latrofa, M.S.; Iatta, R.; Toniolo, F.; Furlanello, T.; Ravagnan, S.; Capelli, G.; Schunack, B.; Chomel, B.; Zatelli, A.; Mendoza-Roldan, J.; et al. A Molecular Survey of Vector-Borne Pathogens and Haemoplasmas in Owned Cats across Italy. Parasit. Vectors 2020, 13, 116. [CrossRef]

92. Müller, K.E.; Zampieri, R.A.; Aoki, J.I.; Muxel, S.M.; Nerland, A.H.; Floeter-Winter, L.M. Amino Acid Permease 3 (Aap3) Coding Sequence as a Target for Leishmania Identification and Diagnosis of Leishmaniases Using High Resolution Melting Analysis. Parasit. Vectors 2018, 11, 421. [CrossRef]

93. Brianti, E.; Celi, N.; Napoli, E.; Abbate, J.M.; Arfuso, F.; Gaglio, G.; Iatta, R.; Giannetto, S.; Gramiccia, M.; Otranto, D. Treatment and Long-Term Follow-up of a Cat with Leishmaniosis. Parasit. Vectors 2019, 12, 121. [CrossRef]

94. Richter, M.; Schaarschmidt-Kiener, D.; Krudewig, C. Ocular Signs, Diagnosis and Long-Term Treatment with Allopurinol in a Cat with Leishmaniasis. Schweiz Arch Tierheilkd 2014, 156, 94. [CrossRef]

95. Tasbihi, M.; Shekari, F.; Hajjaran, H.; Khanmohammadi, M.; Hadighi, R. Comparative Mitochondrial Proteomics of Leishmania Tropica Clinical Isolates Resistant and Sensitive to Meglumine Antimoniate. Parasitol. Res. 2020, 119, 1857-1871. [CrossRef]

96. Adinehbeigi, K.; Razi Jalali, M.H.; Shahriari, A.; Bahrami, S. In Vitro Antileishmanial Activity of Fisetin Flavonoid via Inhibition of Glutathione Biosynthesis and Arginase Activity in Leishmania Infantum. Pathog. Glob. Health 2017, 111, 176-185. [CrossRef] [PubMed]

97. Ribeiro, R.R.; Michalick, M.S.M.; da Silva, M.E.; Dos Santos, C.C.P.; Frézard, F.J.G.; da Silva, S.M. Canine Leishmaniasis: An Overview of the Current Status and Strategies for Control. Biomed. Res. Int. 2018, 2018, 3296893. [CrossRef] [PubMed]

98. Brianti, E.; Falsone, L.; Napoli, E.; Gaglio, G.; Giannetto, S.; Pennisi, M.G.; Priolo, V.; Latrofa, M.S.; Tarallo, V.D.; Solari Basano, F.; et al. Prevention of Feline Leishmaniosis with an Imidacloprid 10\%/Flumethrin 4.5\% Polymer Matrix Collar. Parasit. Vectors 2017, 10, 334. [CrossRef]

99. Fernández Cotrina, J.; Iniesta, V.; Monroy, I.; Baz, V.; Hugnet, C.; Marañon, F.; Fabra, M.; Gómez-Nieto, L.C.; Alonso, C. A Large-Scale Field Randomized Trial Demonstrates Safety and Efficacy of the Vaccine LetiFend®against Canine Leishmaniosis. Vaccine 2018, 36, 1972-1982. [CrossRef] [PubMed]

100. Moreno, J.; Vouldoukis, I.; Martin, V.; McGahie, D.; Cuisinier, A.-M.; Gueguen, S. Use of a LiESP/QA-21 Vaccine (CaniLeish) Stimulates an Appropriate Th1-Dominated Cell-Mediated Immune Response in Dogs. PLoS Negl. Trop. Dis. 2012, 6, e1683. [CrossRef] [PubMed] 